Article

\title{
Transparency in EU Trade Policy: A Comprehensive Assessment of Current Achievements
}

\author{
Axel Marx ${ }^{1, *}$, Guillaume Van der Loo ${ }^{2}$ \\ ${ }^{1}$ Leuven Centre for Global Governance Studies, University of Leuven, 3000 Leuven, Belgium; \\ E-Mail: axel.marx@kuleuven.be \\ 2 University of Ghent, 9000 Ghent, Belgium, E-Mail: guillaume.vanderloo@ugent.be \\ * Corresponding author
}

Submitted: 23 October 2020 | Accepted: 30 December 2020 | Published: 31 March 2021

\begin{abstract}
The EU trade policy is increasingly confronted with demands for more transparency. This article aims to investigate how transparency takes shape in EU trade policy. First, we operationalize the concept of transparency along two dimensions: a process dimension and an actor dimension. We then apply this framework to analysis of EU Free Trade Agreements (FTAs). After analyzing transparency in relation to FTAs from the perspective of the institutional actors (Commission, Council and Parliament), the different instruments and policies that grant the public actors (civil society and citizens) access to information and documents about EU FTAs are explored by discussing Regulation 1049/2001, which provides for public access to European Parliament, Council and Commission documents, and the role of the European Ombudsman. The article is based on an analysis of official documents, assessments in the academic literature and case-law of the Court of Justice of the European Union. The ultimate aim is to assess current initiatives and identify relevant gaps in the EU's transparency policies. This article argues that the EU has made significant progress in fostering transparency in the negotiation phase of FTAs, but less in the implementation phase.
\end{abstract}

\section{Keywords}

European Commission; European Council; European Parliament; Free Trade Agreements; Ombudsman; regulation; trade policy; transparency

Issue

This article is part of the issue "Access or Excess? Redefining the Boundaries of Transparency in the EU's Decision-Making" edited by Camille Kelbel (Lille Catholic University, France), Axel Marx (University of Leuven, Belgium) and Julien Navarro (Lille Catholic University, France).

(C) 2021 by the authors; licensee Cogitatio (Lisbon, Portugal). This article is licensed under a Creative Commons Attribution 4.0 International License (CC BY).

\section{Introduction}

Many policy areas and institutions have been confronted by an increasing demand for transparency and access to information in order to enhance legitimacy and accountability (Peters, 2016, p. 6). Transparency is often seen as "part and parcel of a principle of democratic governance" (Bianchi, 2013, p. 4). This is also recognized in EU law (Delimatsis, 2017) and EU policy-making (Hillebrandt, Curtin, \& Meijer, 2014). As a result, measures to enhance transparency are introduced, including in relation to trade policy. The previous European Commission's Trade for All strategy prioritized transparency initiatives, for example by making public draft negotiation texts of Free Trade Agreements (FTAs). Under the new von der Leyen Commission, transparency in the EU's trade policy will be further strengthened: 'Making trade more transparent' is indeed identified as one of the key priorities for the new Commission (von der Leyen, 2019).

This turn towards transparency has received increased attention by researchers focusing on EU trade policy and EU FTAs. First, some researchers focused on 
the consequences of increased transparency for EU trade policy with a focus on accountability (Coremans, 2019a), exchange of information and the inclusion of expertise and knowledge in trade policy (Chalmers, 2013), the inclusion of preferences in trade negotiations (Dür \& De Bièvre, 2007; Woll, 2009) and possible consequences related to an increase of transaction costs (Coremans, 2019b). Second, researchers have focused on how transparency plays out in trade policy from the perspective of specific institutional actors such as the European Parliament (EP-hereafter; Coremans \& Meissner, 2018); Council (Hillebrandt, 2017) and European Commission (Coremans, 2017). Third, researchers focused on specific instruments to enhance transparency such as access to documents legislation (Hillebrandt \& Abazi, 2015) and inter-institutional agreements (Rosén \& Stie, 2017). Here research focuses on the design of the agreements and an assessment of their potential contribution to enhance transparency. Fourth, researchers have analyzed specific trade agreements. The Transatlantic Trade and Investment Partnership (TTIP) negotiations between the EU and the United States led to an unprecedented level of contestation of EU FTAs by CSOs and MEPs. In addition to concerns about the agreement's potential negative impact on, inter alia, the governments' right to regulate and environmental, consumer and food safety standards, many activists and social groups complained about the 'secrecy' of the negotiations, implying that the EU was negotiating behind closed doors without sufficiently informing the public (Gheyle \& De Ville, 2017; Heldt, 2020) and the EP (Meissner, 2016). Finally, recent debates around the Comprehensive Economic and Trade Agreement (CETA) between the EU and Canada brought the role of national parliaments in EU member states into the picture as one mechanism to enhance transparency (Wouters \& Raube, 2018).

Our contribution builds on these approaches and aims to make three contributions. First, we offer an integrated analysis of the achievements of enhancing transparency in EU trade policy along several dimensions. Previous studies focused on very specific components of transparency in EU trade policy and the making of EU FTAs. Through a comprehensive assessment of transparency measures in EU trade policy, we aim to identify the areas where the most progress has been made and where progress has been lacking. Secondly, we update current developments with regard to institutional transparency by covering the most recent case law of the Court of Justice of the EU (CJEU). Previous contributions on institutional transparency focused on changes introduced by the Lisbon Treaty and were to a degree speculative since they analyzed potential challenges. Several years onward, recent case law allows us to better assess the real challenges related to institutional transparency. Third, the integrated assessment and discussion of recent case law leads us to develop the argument that transparency increased with regard to the negotiations of FTAs but less with regard to their implementation.
Based on existing literature and an in-depth analysis of primary legal documents, we sketch the different pathways in which transparency is operationalized in current EU trade policy. In order to do this, we first develop a framework to analyze transparency in EU trade policy and next, for each component, we present and discuss the main pathways in which transparency is operationalized.

\section{Framework for Comprehensive Assessment of Transparency in Trade Policy}

In order to provide for a comprehensive analysis of transparency in EU FTAs we develop a framework along two dimensions. Several authors have focused on conceptually disentangling transparency into different dimensions and components (see, e.g., Coremans, 2017). For the purpose of this article we distinguish two dimensions which are especially relevant for analyzing EU trade policy: an actor dimension and a process dimension.

The first dimension, the actor dimension, focuses on the interactions between actors in a policymaking or rule-making process such as the negotiation of trade agreements. In Meijer's (2013, p. 430) approach transparency is defined as "the availability of information about an actor that allows other actors to monitor the workings of performance of the first actor." The actors in the context of the EU are manifold. On the one hand there are the actors which are formally involved in negotiating and implementing trade agreements: the Commission, the Council and the Parliament. On the other hand, there are the actors, or stakeholders, who have a 'stake' or interest in trade policy for multiple reasons. This implies that transparency needs to be created between numerous actors. In this context Ostry (2004; see also Coremans, 2019a) makes a distinction between public and institutional transparency. Institutional transparency focuses on information disclosure between institutional actors. Public transparency, in turn, focuses on the relationship between external stakeholders, or 'the public,' on the one hand and each of the EU institutions (EP, Council and Commission) on the other hand. Such an actor-based distinction is also proposed by Rosén (2018), who focuses on the interactions between the executive and public on the one hand and the executive and EP on the other hand.

In exploring the institutional dimension of transparency in EU trade policy, it is worthwhile to first reiterate some of the key components of the EU trade policy-making process. Indeed, taking into account the EU's internal political structure and how the three main governing institutions (the EP, the Council and the Commission) interact with each other is crucial in assessing transparency. Trade policy is an exclusive EU competence (Article 207 of the TFEU), where the EU as a single entity concludes trade agreements with third countries and has the power to legislate on trade matters, whereas individual member states do not. The EU 
FTA-making process involves the interaction and participation of the different EU institutions at different stages. The Commission requests authorization from the Council to negotiate a trade agreement. Such authorization includes 'directives,' which outline the mandate of what the Commission should seek to achieve in the agreement. The Commission then negotiates with the trading partner on behalf of the EU. During this negotiation, the Commission works closely with the Council's trade policy committee (TPC) and keeps the EP fully informed. It must also hold meetings with representatives from CSOs and publishes EU position papers, proposed agreement texts and reports of the negotiations. Under the 2007 Treaty of Lisbon, the EP is a co-legislator on trade and investment alongside the Council. International trade agreements therefore require parliamentary approval before they can enter into force. Once negotiations are complete, the Commission publishes the agreement and proposes the deal to the Council, who then needs decide on its signature. After signature (together with the other contracting parties), both the Council and the EP need to approve the agreement in order to ratify the agreement on behalf of the Union. During and after the negotiations of an agreement, a set of procedures is set in place through which all institutional (three EU institutions) and public (CSO) actors engage in information exchange.

The second dimension, the process dimension, frames trade-policy as a process of negotiation and implementation (Abbott \& Snidal, 2009). In this dimension, there is a focus on transparency measures taken in the different stages of negotiating and implementing a trade agreement. This distinction corresponds to the distinction made by Auld and Gulbrandsen (2010) with regard to procedural and outcome transparency and the distinction proposed by Martínez (2013) between documentary, decision-making and operational transparency. In the negotiation of trade agreements there are demands to have access to negotiation mandates and documents on developments in negotiations. Concerning implementation, there are demands for greater transparency in terms of monitoring and fostering compliance with the commitments laid down in a trade agreement.

In sum, for the purpose of this article, we approach transparency as a set of rules and procedures on the provision of relevant information to-and betweeninstitutional and public actors involved in the trade process throughout the entire trade process (from negotiating to implementing FTAs). In the next sections we apply this framework to the different initiatives geared towards enhancing transparency in EU trade policy. We divide the discussion on the actor dimension and within each actor dimension we focus on the process dimension.

\section{Institutional Transparency}

The discussion relating to transparency in FTA negotiations revolves around the conditions under which the
EU institutions (and citizens) have access to negotiating documents. The following section focuses on the conditions, extent, and limits of such access to documents throughout the entire process of EU FTAs for the EP and the Council.

\subsection{The EP}

Transparency has been reinforced with the strengthening of the EP's right to be informed following the Treaty of Lisbon. The Treaty of Lisbon brought three crucial changes with regard to the role of the EP in the EU's trade policy (Devuyst, 2014; Kleinman, 2011; Krajewski, 2012; Van den Putte, De Ville, \& Orbie, 2014). First, under Article 218(6)(a)(v) of the TFEU, the EP obtained the right to give its consent to trade agreements, as this is an area where the ordinary legislative procedure applies (Article 207(2)). Secondly, under Article 218(10), it obtained the right to be 'immediately and fully informed' at all stages of the procedure of negotiating and concluding (trade) agreements. Lastly, the Parliament became co-legislator on trade legislation under the ordinary legislative procedure (Article 207(2)). The first two innovations are closely intertwined. As the EP's consent is required for the conclusion of EU FTAs, it is crucial that the Parliament's position and concerns are known-and addressed-during the negotiations to avoid the agreement being rejected by the Parliament at the final stages of the EU's ratification process. On several occasions, the EP has already demonstrated that it is not afraid to reject international agreements in the final ratification stage, such as in the case of the Anti-Counterfeiting Trade Agreement, the SWIFT Agreement and the 2011 EU-Morocco Fisheries Partnership Agreement.

In order to avoid such scenarios, Article 218(10) of the TFEU states that the EP needs to be "immediately and fully" informed at all stages of the procedure. Significantly, this right to information also applies equally to international agreements for which the Parliament only needs to be consulted or is not involved during the ratification procedure (i.e., agreements relating exclusively to the Common Foreign and Security Policy; Articles 218(6)b and 218(6) of the TFEU; Parliament v. Council (Mauritius), 2014). Moreover, Article 207(3) of the TFEU specifies the information requirement with regard to trade agreements by requiring the Commission to "report regularly to [the Council's TPC] and to the European Parliament on the progress of negotiations."

In 2010, the EP and Commission concluded an Interinstitutional Framework Agreement (hereafter IFA) that sought to strengthen the new 'special partnership' between Parliament and the Commission in the postLisbon institutional framework by, inter alia, improving the flow of information between the two institutions, including in relation to international (trade) agreements (IFA, 2010, Article 1). 
Concerning international agreements, this IFA provides that the Commission simultaneously needs to inform the EP and the Council about its intention to propose the start of negotiations, present draft negotiating directives to the EP and to "take due account of European Parliament's comments throughout the negotiations" (IFA, 2016, Annex III). Moreover, the Commission committed itself to keeping the EP regularly informed about the progress of negotiations. In addition, the Commission needs to show whether and how EP's comments were integrated in the texts under negotiation (IFA, 2016, Annex III). In the case of international agreements that require the EP's consent, the Commission also agreed to provide to the EP all relevant information that it also provides to the Council during the negotiations. This includes draft amendments to adopted negotiating directives, draft negotiating texts, agreed articles, the agreed date for initialing the agreement and the text of the agreement to be initialed. This provision of information from the Commission to the EP and Council also includes any relevant documents received from third parties, if these third parties agree with their disclosure. Finally, the Commission granted the EP rights of access to negotiation meetings by, for instance, facilitating conditional participation of MEPs (as observers) in relevant meetings before and after negotiation sessions (IFA, 2016, para. 25).

Hence, the IFA granted the EP unprecedented rights of information and access to meetings of the Commission (Devuyst, 2014; Kleinman, 2011). The Council criticized this IFA between the Commission and EP since it grants the EP access to confidential information. It is therefore no surprise that the duty to inform, codified in Article 218(10) of the TFEU, led to a number of disputes, some of which ended up before the Court of Justice. The EP notably initiated-and ultimately prevailed-in two cases brought against the Council because of the failure of the latter to transmit relevant documents, both concerning agreements on the transfer of pirates with, respectively, Mauritius (Parliament v. Council (Mauritius), 2014) and Tanzania (Parliament v. Council, 2016).

In Parliament v. Council (Mauritius) (2014), the Court ruled that the Council violated the information requirement under Article 218(10) of the TFEU by informing the EP of a decision on signature over three months after its publication in the Official Journal (Parliament $v$. Council (Mauritius), 2014, para. 77-78). The Court considered the notification to the EP an essential procedural requirement within the meaning of the second paragraph of Article 263 of the TFEU, the violation of which leads to nullity of the decision (Parliament $v$. Council (Mauritius), 2014, para. 80). In the Tanzania case, the Court went a step further and clarified that the obligation of Article 218(10) of the TFEU applies to any procedure for concluding an international agreement (so not only, for example, trade agreements, but even agreements relating exclusively to the Common Foreign and Security
Policy; Parliament v. Council, 2016, para. 68). The Court recalled that "participation by the EP in the legislative process is the reflection, at Union level, of a fundamental democratic principle that the people should participate in the exercise of power through the intermediary of a representative assembly" (Commission of the European Communities v. Council of the European Communities, 1991, para. 20; European Parliament v. Council of the European Union, 2012, para. 81; SA Roquette Frères v. Council of the European Communities, 1980, para. 33). As regards the procedure for negotiating and concluding international agreements, the Court argued that "the information requirement laid down in Article 218(10) of the TFEU is the expression of that democratic principle, on which the European Union is founded" (Parliament $v$. Council (Mauritius), 2014, para. 81). In particular, the aim of the information requirement of Article 218(10) of the TFEU is, inter alia:

To ensure that the [European] Parliament is in a position to exercise democratic control over the European Union's external action and, more specifically, to verify that the choice made of the legal basis for a decision on the conclusion of an agreement was made with due regard to the powers of the [European] Parliament. (Parliament v. Council (Mauritius), 2014, para. 71).

The Court further clarified that Article 218(10) of the TFEU also extends to the stages that precede the conclusion of such an agreement, and covers, in particular, the negotiation phase which includes, inter alia, the authorization to open negotiations, the definition of the negotiating directives, and in some cases, the designation of a special committee, the completion of negotiations, the authorization to sign the agreement where necessary, and the decision on the provisional application (Parliament v. Council (Mauritius), 2014, para. 75).

The Court found that the obligation to inform the EP on the conduct of negotiations rests on the shoulders of the Council (Parliament v. Council (Mauritius), 2014, para. 73). To the extent that this involves the transmission of Council decisions, this is logical. However, it has been questioned whether it is logical to make the Council responsible for informing the EP of the negotiations themselves, as the Council is normally not represented at negotiation sessions (Driessen, 2020). The TPC are themselves debriefed some time (often weeks) after negotiation rounds and are thus not in a position to debrief the EP 'immediately.' In practice it is indeed the Commission rather than the Council that debriefs the EP.

Following these cases, the three institutions agreed to search for solutions on a tripartite basis. In the interinstitutional agreement on better law-making of 2016, they acknowledged the importance of "ensuring that each institution can exercise its rights and fulfil its obligations enshrined in the Treaties as interpreted by the Court of Justice" regarding the negotiation 
and conclusion of international agreements (IFA, 2016, p. 1). The agreement on better law-making envisaged special negotiations on improved practical arrangements for cooperation and information sharing in the context of international agreements (IFA, 2016, para. 41). These arrangements are intended to consolidate the information and scrutiny rights of the EP, so as to allow it to ensure the democratic legitimacy of the decisional process in the area of international agreements. However, the negotiations on this delicate issue have stalled.

The analysis above illustrates that academic and policy discussions about the EP's right of information with regard to international (trade) agreements focused so far mainly on the negotiation phase of EU trade agreements, thus on the negotiation component of the process dimension of transparency (as conceptualized in this article). However, there is increasingly attention to the (lack of) involvement of the EP in relation to the implementation of trade agreements by common bodies established by such agreements, thus on the implementation component of the process dimension of transparency (Weiss, 2018). Whereas international agreements concluded by the EU have always set up common bodies to facilitate their own amendment and implementation, the new generation of EU FTAs makes use of such bodies, often in the form of committees. These committees increasingly have extensive competences, including legislative powers to amend the trade agreement, to change the institutional architecture of the agreement, to adopt regulatory decisions or to give binding interpretation to provisions of the agreement. The EP is not involved in decisions taken by the FTA bodies, as representatives of the EP are not represented nor participate in these bodies. Article 218(9) of the TFEU provides that for significant amendments, the Council adopts the position to be taken by the EU in a treaty body based on a proposal by the Commission. For simplified amendments, Article 218 (7) of the TFEU provides for a simplified procedure whereby an amendment is agreed to by a negotiator, usually the Commission, acting under authorization by the Council (Weiss, 2018). In both instances, the EP is not involved in the decision-making of the Council decision. Contrary to the Council, the EP is not even consulted by the Commission during the negotiations of such decisions by joint bodies. It is only when the Commission has agreed with the FTA partner the substance of the decision to be adopted in the joint body/committee that the Commission makes a proposal for a Council decision on the position to be taken on behalf the EU in that joint body, which includes the draft decision of the joint body-and which is transmitted to the EP.

Significantly, decisions of such committees and joint bodies may create new rules by way of their legislative and regulatory functions whose adoption internally in the EU would have required the involvement of the EP under, for example, the ordinary legislative procedure. Therefore, the legitimacy of decisions of common bodies established by EU FTAs is questioned (Weiss,
2018), although it can be argued that the legitimacy of committee decisions might ultimately stem from the EP's consent to the agreement, as this implies that the EP agreed to the treaty-body decision-making mandates provided therein.

It is not entirely clear to what extent the information requirement under Article 218(10) of the TFEU obliges the Council to inform the EP of-preparations of-decisions of joint bodies under EU FTAs, as this has not explicitly been addressed by the Court or the IFA. Therefore, it has been argued that the information requirements should be further specified and expanded, for example by modifying the current IFA to give the MEPs observer status in treaty bodies of EU FTAs, similar to the status of observers part of the EU delegation at international conferences, or to guarantee that the EP receives complete and timely information at all stages of the procedure with regard to envisaged treatybody decisions.

It is also important to note in this regard that whereas the (draft) decisions of such joint FTA bodies are in principle annexed to the Commission proposal for the Article 218(9) of the TFEU Council decision, or are included in the Council's document register after adoptionand are therefore accessible-the FTAs do not explicitly require that such decisions have to be made public after adoption by the joint body. Recent FTAs, however, aim to make such decisions public. For example, the EU-Canada CETA and the EU-Japan FTA do not explicitly oblige their respective Joint Committees to make public its decisions; however, its Rules of Procedure (adopted as decisions of the respective Joint Committees) specify that "the parties to the agreement will ensure that the decisions, recommendations or interpretations adopted by the Joint Committee are made public" (CETA, Article 26.3; CETA Joint Committee, rule 10). The Rules of Procedure also specify that the agenda and a (summary of) the minutes of these meetings can be made public by the Parties, unless one of the Parties submits that these documents have to remain confidential (CETA, Article 26.4; CETA Joint Committee, rule 9).

As noted above, the implementation component of the process dimension of transparency also covers the enforcement of FTAs. Similar to the situation of the implementation of FTAs by joint bodies set up by such agreements, the EP is hardly involved in enforcement procedures. This can be illustrated by the State-to-State dispute settlement mechanisms (DSMs) provided for in the new generation of EU FTAs that deal with disputes concerning the interpretation or application of these agreements. Although such DSMs have become standard practice in EU FTAs (Bercero, 2006), they are hardly being used (European Commission, n.d.). The Commission is representing the Union in these cases (Council v. Commission (ITLOS), 2015) by requesting the DSM consultations and eventually the establishment of the arbitration panel and by representing the Union during the arbitration proceedings. Significantly, there is no 
legal obligation on the Commission to inform or consult the Parliament about the (potential) initiation of such DSM procedures, or the legal position taken therein, although it is required to consult the Council. The Court indeed stressed in the Tanzania case (Parliament v. Council, 2016) that the information obligation under Article 218(10) of the TFEU implies that the EP must be informed at all the different negotiations stages leading up to the entry into force of the agreement, but it did not mention the implementation or enforcement of EU FTAs (Parliament v. Council (Mauritius), 2014, para. 76). Also, the IFA remains silent on this issue. However, in practice the Commission (usually the Head of Unit on Dispute Settlement) informs a delegation of the INTA Committee every 6 months in camera about DSM proceedings under FTAs.

This does not mean that MEPs (or public actors such as citizens or CSOs) have no access at all to relevant documents about such arbitration proceedings. EU FTAs require that the hearings of the arbitration panel are in principle open to the public and that the parties make their submissions publicly available. However, the arbitration panel can meet in a closed session when the submission and arguments of a party contain confidential business information. However, in this case a nonconfidential version of the submission needs to be made public (CETA, Annex 29-A). Also, the final report must be made publicly available (CETA, Article 29.10), but the interim report can be confidential (CETA, Article 29.9). Moreover, DSMs under EU FTAs allow CSOs to submit amicus curiae briefs (CETA Annex 29-A).

The EP's limited role in such DSM proceedings is also visible in the selection procedure of the arbitrators. The list of arbitrators is usually established by the Joint Committee set up by the FTA. On the EU's side, this requires a Council Decision on the position to be taken on behalf of the EU in that Committee, based on Article 218(9) of the TFEU. As noted above, the EP is not involved in this procedure, implying that the EP has, for example, no means to check if the EU's (proposed) arbitrators are meeting the necessary professional requirements (see, for example, CETA Article 29.8(2)).

\subsection{The Council}

Although the policy and academic discussions on transparency with regard to EU FTAs mainly focus on the right of information of the EP during the negotiation of trade agreements, it is important to note that the Council has also aimed to expand its right to information during the negotiation of international (trade) agreements. Article 218(4) of the TFEU provides that the Council may address directives to the Commission as negotiator and establish a committee which needs to be consulted during the negotiations. With regard to trade agreements, Article 207(4) of the TFEU stipulates that after the Council has authorized the Commission to open negotiations, the Commission needs to conduct these negoti- ations in consultation with the TPC. The Commission is required to regularly report to the TPC and to the EP on the progress of negotiations.

In the gas emissions case (Commission v. Council (Gas emissions), 2015), which concerned the negotiation of an agreement with Australia on greenhouse gas emissions trading schemes, the CJEU considered the rights and obligations of an Article 218(4) of the TFEU committee. The Court ruled that the Commission is obliged to provide the Article 218(4) of the TFEU committee with:

All the information necessary for it to monitor the progress of the negotiations, such as, in particular, the general aims announced and the positions taken by the other parties throughout the negotiations. It is only in this way that the special committee is in a position to formulate opinions and advice relating to the negotiations. (Commission v. Council (Gas emissions), 2015, para. 66)

The Commission can even be required to provide such information to the Council (Commission v. Council (Gas emissions), 2015, para. 67). Moreover, the Court even accepted that the Council could impose procedural requirements with regard to information provision and consultation between the established committee and the Commission in the negotiating directives (Commission v. Council (Gas emissions), 2015, para. 78). However, the Court also established limits to the Council's ability to direct the negotiation (Cremona, 2017). In particular, the Court held that neither the Council nor Council Committees have the right to establish detailed negotiating positions that bind the Commission, as this would jeopardize the institutional balance laid down in the Treaties, would go beyond the consultative function given to the committee by Article 218(4) of the TFEU and would be an infringement of the Commission's prerogatives as negotiator (Commission v. Council (Gas emissions), 2015, para. 89-90).

Less attention has been devoted to the Council's right of access to documents in the implementation phase of international trade agreements. As noted above, the Commission is in charge of the negotiation with the FTA partner of decisions of joint committees established by FTAs, and must then make a proposal for a Council decision regarding the position to be adopted on the EU's behalf in such joint bodies (Article 218(9) of the TFEU; Van Elsuwege \& Van der Loo, 2019). Only after the adoption of the Article 218(9) of the TFEU decision by the Council, the joint committee can adopt the actual decision. The Commission consults the Council in the TPC about such negotiations before it adopts its proposal for an Article 218(9) of the TFEU Council decision. The Council is therefore in principle informed in a timely manner and consulted with regard to such Article 218(9) of the TFEU decisions, however, it is not always immediately informed about the actual adoption of the decision of 
the joint committee (for which the Commission is responsible). As noted above, such decisions are not always made public-although recent EU FTAs make efforts in this regard.

A similar procedure also applies with regard to enforcement of EU FTAs by DSM cases. As confirmed by the Court in Council v. Commission (ITLOS) (2015, para. 86), in view of the principle of sincere cooperation, the Commission is required to consult the Council beforehand if it intends to express positions on behalf of the EU before an international Court. The Commission therefore consults the Council in the TPC or in other Council Committees before every step in such arbitration proceedings (e.g., request for consultations or the establishment of a panel). Moreover, representatives of the member states are allowed to be present during the DSM proceedings, but are not allowed to contribute.

In view of the above, it can be concluded that there are sufficient procedures to ensure that the Council is informed in a timely manner or consulted by the Commission, both in relation to the implementation of FTAs and the enforcement of FTAs.

\section{Public Transparency}

The following section analyzes the access to information and transparency-related instruments and procedures in the EU's FTA policy involving public actors (i.e., civil society and citizens). The most important instruments or procedures that give public actors information about EU trade agreements are the access to documents Regulation 1049/2001 (European Commission, 2019) and the European Ombudsman.

\subsection{The Access to Documents Regulation 1049/2001}

Access to documents is, in the EU, governed by Regulation 1049/2001 (hereinafter Regulation). This Regulation builds on the principle of 'widest possible access,' and has together with case law of the CJEU, been instrumental in operationalizing the Treaty commitments with regard to the right of citizen access to documents and transparency. Any citizen of the Union, and any natural or legal person residing or having its registered office in a member state, has a general right of access to documents of the institutions (i.e., the $E P$, Council and the Commission), subject to the principles, conditions and limits defined in the Regulation. According to Article 4 of the Regulation, refusal of access to a document can be allowed only in cases where disclosure could undermine the protection of one of the public (international relations and security) or private (protection of personal data, commercial interests, court proceedings and legal advice) interests listed in that provision. Exceptions to the general principle of public access to documents should, following established case-law, be interpreted and applied narrowly (see Access Info Europe v. Commission, 2018a, 2018b; ClientEarth v. Commission, 2015). Hence, the Regulation contains a mandatory exception to disclosure of documents which would undermine the protection of the public interest as regards international relations (Article $4(1)(a)$ ) third indent of the regulation) or where disclosure would undermine, inter alia, court proceedings and legal advice, unless there is an overriding public interest in disclosure (Article 4(2)). The Court has acknowledged in several cases the wide margin of discretion held by the EU institutions in this framework (Access Info Europe v. Commission, 2018b, para. 40-41; ClientEarth v. European Commission, 2018, para. 23-24). The General Court therefore concluded that the exception for the protection of international relations is therefore subject to a limited judicial review of legality that is circumscribed to verifying the compliance with the procedural rules and the duty to state reasons, the accuracy of the statement of facts, and the lack of a manifest error of assessment or a misuse of powers (ClientEarth $v$. European Commission, 2018, para. 23).

Significantly, the Regulation has increasingly been used, including by MEPs, to challenge Council and Commission refusals to grant access to information during negotiations of international (trade) agreements. Two cases brought forward by MEP Sophie In't Veld are important in this context. In a first case, in 2009, In't Veld made a request for access to the opinion of the Council's Legal Service on the Commission's recommendation to the Council to start the SWIFT negotiations (concerning banking data transfers to the United States via the SWIFT network). Both the General Court and the CJEU in appeal argued that the disclosure of the positions taken within the EU institutions concerning the appropriate legal basis for the agreement would not have posed a threat to the EU's international relations interests within the meaning of Article 4(1)a of the Regulation (Council v. In't Veld, 2014). On the other hand, both courts clarified the contours of transparency in that they agreed that access can be refused for documents that relate to the specific content of international agreements (this would arguably include draft text and proposals by the EU) and the negotiating directives which relate to the strategic objectives pursued by the EU in the negotiations with a third country (Council v. In't Veld, 2014, para. 58).

The second case concerned a Commission decision to refuse access to certain documents relating to the AntiCounterfeiting Trade Agreement (In't Veld v. Commission, 2013). The EP refused to give its consent to the AntiCounterfeiting Trade Agreement. The EP criticized the Commission for a lack of transparency in the negotiation process. The Commission only disclosed a limited number of documents. Access to most documents was refused with reference to the 'international relations' exception of the Regulation. The case was partially successful for In't Veld. However, the Court also recognized the validity of the argument by the Commission that the public disclosure of negotiating positions and negotiations could compromise the EU's negotiating position 
and undermine EU interests. Hence, according to the Court, the negotiation of international agreements could justify "a certain level of discretion to allow mutual trust between negotiators and the development of a free and effective discussion" (In't Veld v. Commission, 2013, para. 119). Moreover, since negotiations are conducted by the executive, public participation in the process was "necessarily restricted" (In't Veld v. Commission, 2013, para. 120). Finally, it was argued that the disclosure of the EU's position could "reveal, indirectly, [the positions] of other parties to the negotiations" (In't Veld $v$. Commission, 2013, para. 124).

It can be observed that in the area of FTA negotiations most of the requests for documents under the Regulation, including the related case law, deal with the negotiation phase of the process dimension of transparency (European Commission, 2019). The Court even clarified recently that, whilst acknowledging Commission's need for space for deliberation on policy choices, documents drawn up in the context of an impact assessment also fall under the general right to access to documents (Case C-57/16). However, it seems that the Regulation is hardly being used to request documents relating to the implementation phase of EU FTAs. The Regulation could be applied to obtaining documents relating to the positions taken by the $\mathrm{EU}$ in joint bodies or committees or documents prepared in the context of DSMs. So far, such an application has not been triggered. As a result, the CJEU has not had the opportunity to clarify the application of the Regulation in relation to documents relating to the implementation of EU FTAs.

\subsection{The European Ombudsman and Transparency Cases about EU FTAs}

The European Ombudsman has become an important player in the EU's transparency framework. Around one quarter of the inquiries the Ombudsman carries out every year concern the lack of or refusal to provide information. For example, concerns about transparency and access to documents in the EU administration (mainly in relation to the Commission) accounted for the biggest proportion of the Ombudsman's cases (24.6\%) in 2018 (European Ombudsman, 2018). These statistics confirm the significant increase in the number of new enquiries observed since 2017, and reflect the growing importance placed by the European Ombudsman on this specific area of activity (European Commission, 2019). Significantly, the European Ombudsman is increasingly dealing with transparency inquiries with regard to the negotiation and conclusion of FTAs, often initiated by NGOs.

One of the most significant inquiries in this area was related, not surprisingly, to the TTIP. In July 2014, the Ombudsman opened an investigation on her own initiative into the transparency of the TTIP negotiations, triggered by concerns about the non-disclosure of key documents and the alleged granting of privileged access to a limited number of stakeholders
(European Ombudsman, 2015b). In closing this inquiry, the Ombudsman welcomed the Commission's transparency initiatives launched in the context of the TTIP negotiations, but also noted that they did not go far enough to inform the public. She proposed the establishment of a comprehensive list of TTIP-related documents, including agendas and minutes of meetings with lobbyists (European Ombudsman, 2015a).

In addition, the Ombudsman carried out several other important inquires in which it called for more transparency and access to documents with regard to the negotiation of EU trade agreements, including recently in relation to briefing material ('flash cards') used by the President of the European Commission in a meeting with the President of the United States Donald Trump. Whereas the Ombudsman generally favours stronger transparency with regard to the negotiation of EU trade agreements in line with the case law of the CJEU discussed above (Abazi \& Adriaensen, 2017), in several cases she concluded that the non-disclosure of several negotiation documents was correct and justified (European Ombudsman, 2018). It can again be observed that, similar to the application of the Regulation, most of the inquiries conducted by the Ombudsman concerning access to FTA documents relate to the negotiation documents, and not to documents adopted in the context of the implementation of FTAs.

\section{Conclusion}

Transparency has significantly increased in the EU's trade policy concerning FTAs. The focus has clearly been on the negotiation phase of FTAs and less on the implementation phase. Of the institutional actors involved in the EU FTAs, the Commission played the most important role in this process, but the Council also, more reluctantly, played a role, providing access to the EP and public actors.

With regard to the institutional actors, we can observe that the EP has secured and materialized its right to be informed during the negotiation phase of FTAs. The interinstitutional relations with the other two internal actors have proven to be essential. Whereas the Commission has been increasingly supportive and cooperative with regard to the EP's quest for more access to FTA negotiation documents, the EP's relations with the Council on this issue remain difficult-as evidenced by the stalled negotiations on practical arrangements for cooperation and information sharing in the context of international agreements under the better law-making agreement. Moreover, EP's involvementand access to documents-remains limited in relation to the implementation of EU FTAs. In particular, in relation to decisions adopted by joint FTA committees, the EP's access to documents-and therefore oversight-is very limited. Considering the increasing importance of such joint bodies in FTAs, it will be crucial that structural interinstitutional procedures are established to keep the 
EP sufficiently in the loop. The renegotiation of the IFA and the relaunching of the negotiations with the Council on practical arrangements for cooperation and information sharing in the context of international agreements could open doors in this regard. Also, towards public actors, transparency has been enhanced by increasingly relying on the access to documents regulation and inquiries by the European Ombudsman. It appears that the access to documents regulation and inquiries by the Ombudsman are mainly used to improve transparency in relation to the negotiation dimension of FTAs.

\section{Acknowledgments}

Research for this article was conducted in the context of the EU's Horizon 2020 Research \& Innovation programme-RECONNECT project (Grant Agreement No. 770142). The authors thank Camille Kelbel and 2 reviewers for comments and feedback.

\section{References}

Abazi, V., \& Adriaensen, J. (2017). EU institutional politics of secrecy and transparency in foreign affairs. Politics and Governance, 5(3), 1-5.

Abbott, K., \& Snidal, D. (2009). Strengthening international regulation through transnational new governance: Overcoming the orchestration deficit. Vanderbilt Journal of Transnational Law, 42, 1-80.

Access Info Europe v. Commission, Case T-851/16, ECLI:EU:T:2018:69 (2018a).

Access Info Europe v. Commission, Case T-852/16, ECLI:EU:T:2018:71 (2018b).

Auld, G., \& Gulbrandsen, L. H. (2010). Transparency in nonstate certification: Consequences for accountability and legitimacy. Global Environmental Politics, 10, 97-119.

Bercero, I. G. (2006). Dispute settlement in European Union Free Trade Agreements: Lessons learned? In L. Bartels \& F. Ortino (Eds.), Regional trade agreements and the WTO legal system (pp. 383-405). Oxford: Oxford University Press.

Bianchi, A. (2013). On power and illusion: The concept of transparency in international law. In A. Bianchi \& A. Peters (Eds.), Transparency in international law (pp. 1-19). Cambridge: Cambridge University Press.

Chalmers, A. W. (2013). Trading information for access: Informational lobbying strategies and interest group access to the European Union. Journal of European Public Policy, 20(1), 39-58.

ClientEarth v. Commission, Case C-612/13, ECLI:EU:C: 2015:486 (2015).

ClientEarth v. Commission, Case C-57/16, ECLI:EU:C: 2018:660 (2018).

ClientEarth v. European Commission, Case T-644/16, ECLI:EU:T:2018:429 (2018).

Commission of the European Communities v. Council of the European Communities, Case C-300/89,
ECLI:EU:C:1991:244 (1991).

Commission v. Council (Gas emissions), Case C-425/13, ECLI:EU:C:2015:483 (2015).

Comprehensive Economic and Trade Agreement, 2017.

Coremans, E. (2017). From access to documents to consumption of information: The European Commission transparency policy for the TTIP negotiations. Politics and Governance, 5(3), 29-39.

Coremans, E. (2019a). Opening up by closing off? Informalisation and transparency in EU trade policy. Leuven: KU Leuven.

Coremans, E. (2019b). Opening up by closing off: How increased transparency triggers informalisation in EU decision-making. Journal of European Public Policy, 27(4), 590-611.

Coremans, E., \& Meissner, K. L. (2018). Putting power into practice: Administrative and political capacity building in the European Parliament's Committee for International Trade. Public Administration, 96(3), 561-577.Council v. Commission (ITLOS), Case C-73/14, ECLI:EU:C:2015:663 (2015).

Council v. In't Veld, Case C-350/12, ECLI:EU:C:2014:2039 (2014).

Cremona, M. (2017). EU Treaty-making: A test case for mutual sincere cooperation? In J. Czuczai \& F. Naert (Eds), The EU as a global actor, bridging legal theory and practice, liber amicorum in honour of Ricardo Gosalbo Bono (pp. 424-439). Leiden and Boston, MA: Brill Nijhoff.

Delimatsis, P. (2017). TTIP, CETA and TiSA behind closed doors: Transparency in the EU trade policy. In S. Griller, W. Obwexer, \& E. Vranes (Eds.), Megaregional trade agreements: CETA, TTIP and TISA: New orientations for EU external economic relations (pp. 216-246) Oxford: Oxford University Press.

Devuyst, Y. (2014). The European Parliament and international trade agreements: Practice after the Lisbon Treaty. In I. Govaere, P. Van Elsuwege, E. Lannon, \& S. Adam (Eds.), The European Union in the world: Essays in honour of Marc Maresceau (pp. 171-189). Leiden and Boston, MA: Martinus Nijhoff Publishers.

Driessen, B. (2020). The Council, the common commercial policy and the institutional balance: Recent developments. In G. Van der Loo \& M. Hahn (Eds.), The law and practice of the common commercial policy: The first 10 years after the Treaty of Lisbon. Leiden and Boston, MA: Brill Nijhoff.

Dür, A., \& De Bièvre, D. (2007). Interest group influence on policymaking in Europe and the United States. Journal of Public Policy, 27(1), 79-101.

European Commission. (n.d.). Disputes under bilateral trade agreements. European Commission. Retrieved from https://ec.europa.eu/trade/policy/accessingmarkets/dispute-settlement/bilateral-disputes

European Commission. (2019). Report on the application in 2018 of Regulation (EC) No 1049/2001 regarding public access to European Parliament, Council and Commission documents (COM (2019)356 final). Brus- 
sels: European Commission.

European Ombudsman. (2015a). Decision of the European Ombudsman closing her own-initiative inquiry Ol/10/2014/RA concerning the European Commission. European Ombudsman. Retrieved from https://www.ombudsman.europa.eu/en/decision/ en/58668

European Ombudsman. (2015b). Report on the European Ombudsman's public consultation in relation to the transparency of the Transatlantic Trade and Investment Partnership (TTIP) negotiations Case Ol/10/2014/RA. European Ombudsman. Retrieved from https://www.ombudsman.europa.eu/en/ correspondence/en/58643

European Ombudsman. (2018). Decision in case 624/2018/TE on how the European Commission dealt with a request for access to list of meetings with stakeholders on the Japan-EU Free Trade agreement. European Ombudsman. Retrieved from https://www.ombudsman.europa.eu/en/decision/ en/93636

European Parliament v. Council of the European Union, Case C-130/10, ECLI:EU:C:2012:472 (2012).

Gheyle, N., \& De Ville, F. (2017). How much is enough? Explaining the continuous transparency conflict in TTIP. Politics and Governance, 5(3), 16-28.

Heldt, E. C. (2020). Contested EU trade governance: transparency conundrums in TTIP negotiations. Comparative European Politics, 18, 215-232.

Hillebrandt, M. Z. (2017). Transparency as a platform for institutional politics: The case of the Council of the European Union. Politics and Governance, 5(3), 62-74.

Hillebrandt, M. Z., \& Abazi, V. (2015). The legal limits to confidential negotiations: Recent case law developments in Council transparency: Access Info Europe and In 't Veld. Common Market Law Review, 52(3), 825-846.

Hillebrandt, M. Z., Curtin, D., \& Meijer, A. (2014). Transparency in the Council of Ministers of the EU: An institutional approach. European Law Journal, 20(1), 1-20.

In't Veld v. Commission, Case T-301/10, ECLI:EU:T:2013: 135 (2013).

Interinstitutional Framework Agreement on relations between the European Parliament and the European Commission (2010).

Interinstitutional Agreement between the European Parliament, the Council of the European Union and the European Commission on Better Law-Making (2016).

Kleinman, D. (2011). Taking stock: Common commercial policy in the Lisbon era. Brussels: CEPS.

Krajewski, M. (2012). The reform of the Common Commercial Policy: Coherent and democratic? In A. Biondi, P. Eeckhout, \& S. Ripley (Eds.), EU law after Lisbon (pp. 292-311). Oxford: Oxford University Press.

Martínez, L. M. (2013). Transparency in international financial. In A. Bianchi \& A. Peters (Eds.), Transparency in international law (pp. 77-111). Cambridge:
Cambridge University Press.

Meijer, A. (2013). Understanding the complex dynamics of transparency. Public Administration Review, 73(3), 429-439.

Meissner, K. L. (2016). Democratizing EU external relations: The European Parliament's informal role in SWIFT, ACTA, and TTIP. European Foreign Affairs Review, 22(2), 269-288.

Ostry, S. (2004). External transparency: The policy process at the national level of the two-level game. In M. Moore (Ed.), Doha and beyond: The future of the multilateral trading system (pp. 94-114). Cambridge: Cambridge University Press.

Parliament v. Council, Case C-263/14, ECLI:EU:C:2016: 435 (2016).

Parliament v. Council (Mauritius), Case C-658/11, ECLI:EU:C:2014:2025 (2014).

Peters, A. (2016). The transparency of global governance. In F. Pazartzis, M. Gavouneli, A. Gourgourinis, \& M. Papadaki (Eds), Reconceptualizing the rule of law in global governance, resources, investment and trade (pp. 3-10). London: Bloomsbury Publishing.

Rosén, G. (2018). Contestation and co-optation: Why secrecy in EU external relations varies. West European Politics, 41(4), 933-957.

Rosén, G., \& Stie, A. E. (2017). Not worth the net worth? The democratic dilemmas of privileged access to information. Politics and Governance, 5(3), 51-61.

SA Roquette Frères v. Council of the European Communities, Case C-138/79, ECLI:EU:C:1980:249 (1980).

Treaty on the Functioning of the European Union, 1957.

Van den Putte, L., De Ville, F., \& Orbie, J. (2014). The European Parliament's new role in trade policy: Turning power into impact (Research Paper No. 89). Brussels: CEPS.

Van Elsuwege, P., \& Van der Loo, G. (2019). Legal basis litigation in relation to international agreements: Commission v. Council (Enhanced Partnership and Cooperation Agreement with Kazakhstan). Common Market Law Review, 56(5), 1333-1354.

von der Leyen, U. (2019, September 10). Mission letter by President-elect of the European Commission Ursula von der Leyen to Phil Hogan, CommissionerDesignate for trade. Brussels: European Commission.

Weiss, W. (2018). Delegation to treaty bodies in EU agreements: constitutional constraints and proposals for strengthening the European Parliament. European Constitutional Law Review, 14(3), 532-666.

Woll, C. (2009). Trade policy lobbying in the European Union: Who captures whom? In D. Coen \& J. Richardson (Eds.), Lobbying the European Union: Institutions, actors and issues (pp. 268-288). Oxford: Oxford University Press.

Wouters, J., \& Raube, K. (2018). Rebels with a cause? Parliaments and EU trade policy after the Treaty of Lisbon. In J. Santos Vara \& S. Rodríguez SánchezTabernero (Eds.), The democratisation of EU international relations through EU law (pp. 210-238). London: Routledge. 


\section{About the Authors}

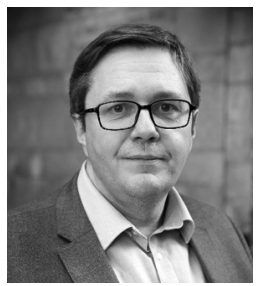

Axel Marx is Deputy Director at Leuven Centre for Global Governance Studies, University of Leuven. He studied in Leuven, Hull and Cambridge and holds a PhD from the University of Leuven. His research interests include voluntary sustainability standards, sustainable development, business and human rights, global governance, governance through trade, EU trade policy and comparative case methods.

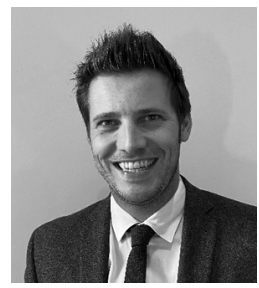

Guillaume Van der Loo (PhD, Ghent University, 2014), is a Research Fellow at the European Policy Centre (Brussels) and Egmont-The Royal Institute for International Relations (Belgium) and Visiting Professor at Ghent University. His research focuses on the law and policy of EU external relations and trade policy. 